\title{
COMPETITIVE MARKETING STRATEGY FOR EUROPE
}




\section{COMPETITIVE \\ MARKETING \\ STRATEGY FOR \\ EUROPE}

DEVELOPING,

MAINTAINING AND

DEFENDING COMPETITIVE

ADVANTAGE

Linden Brown

and

Malcolm H. B. McDonald 
(C) Linden Brown and Malcolm H. B. McDonald 1994

All rights reserved. No reproduction, copy or transmission of this publication may be made without written permission.

No paragraph of this publication may be reproduced, copied or transmitted save with written permission or in accordance with the provisions of the Copyright, Designs and Patents Act 1988, or under the terms of any licence permitting limited copying issued by the Copyright Licensing Agency, 90 Tottenham Court Road, London WIP 9HE.

Any person who does any unauthorised act in relation to this publication may be liable to criminal prosecution and civil claims for damages.

First published 1994 by

THE MACMILLAN PRESS LTD

Houndmills, Basingstoke, Hampshire RG21 2XS

and London

Companies and representatives

throughout the world

ISBN 978-0-333-61351-1 ISBN 978-1-349-23392-2 (eBook)

DOI 10.1007/978-1-349-23392-2

A catalogue record for this book is available

from the British Library.

Typeset by Cambrian Typsetters, Frimley, Surrey 


\section{Contents}

List of Tables vii

List of Figures ix

Acknowledgements xii

\section{Competitive Marketing Strategy: Concepts and} Application 1

The Task of Competitive Marketing Strategy 1

The Strategic Planning Process 2

Strategic Analysis Concepts 7

Integration of Concepts and Models 40

Competitive Position 45

Competitive Strategies $\quad 50$

Case Study 1: Myson Radiator Division 53

2 Low Cost, High Differentiation Strategies 72 Introduction 72

Multibrand Strategies to Protect Dominance 76

Maximising Market Potential and Profit as the Dominant Industry

Force 83

Strategic Issues in Mature and Declining Markets $\quad 88$

Case Study 2: JCB Defends its Dominance in a Declining Market 97

Case Study 3: Andrex 103

Case Study 4: Glaxo 108

3 Low Cost, Low Differentiation Strategies 113

Introduction 113

Developing a Market Leadership Position in Service Industries 115

Case Study 5: The Single European Grocery Market 120

Case Study 6: Leadership Issues in the European Cellopp Market

Case Study 7: Gaining Leadership in an Undifferentiated Market Ratners Group plc $\quad 140$

Attacking the Market Leader 144

Case Study 8: Amstrad Learns from the Japanese Approach 153

Repositioning the Business for Leadership 160

Case Study 9: Tesco 167

Case Study 10: Bernard Matthews 173 


\section{Strategies for Positioning as a Major Force in the} Market 179

Introduction 179

Creating a Third Force

Case Study 11: Ballentine's (Hiram Walker/Allied-Lyons) in Spain

Flanking Strategy and Cost Leadership to Position as a Major Force

Case Study 12: Argos 208

Restructuring the Market to Break Monopolistic Competition

212

Case Study 13: Courtelle 218

Case Study 14: The European Fertiliser Industry

221

Case Study 15: Virgin Atlantic Airways 234

Case Study 16: Pretty Polly 238

Case Study 17: Selincourt 241

5 Growth Strategies for the Niche Competitor 258

Competitive Infiltration Strategies 260

Case Study 18: Europeanising a Medium-size Company 266

Expanding Regional Brands 274

Case Study 19: Firkin Pubs - A London Regional Brand 282

Case Study 20: San Serif and Trivial Pursuit 286

Case Study 21: Derwent Valley Foods Ltd - Marketing Success Story or One Product Wonder? 291

Niche Marketing Against Big Budget Competitors 294

Case Study 22: Stollwerck AG in Germany 299

Case Study 23: Next 302

Case Study 24: The Launch of The Independent Newspaper 312

Case Study 25: Thorntons plc 316

6 Competitive Marketing Strategy Experience

\section{Uses of Case Studies to Enhance Learning 340}

Notes and References

Bibliography 356

Index $\quad 358$ 


\section{$\square$ List of Tables}

1.1 Evolution of management systems 3

1.2 Products at different life-cycle stages 9

1.3 Generic strategy options 23

1.4 Ansoff's growth vector matrix 26

1.5 Using the Ansoff matrix in the objective setting process 27

1.6 Some PIMS findings 31

1.7 European chocolate confectionery market shares (per cent by sales volume) 39

1.8 Guidelines for various product life-cycle stages and competitive positions 41

1.9 Competitive position and life-cycle stage 42

1.10 Portfolio position and life-cycle stage 42

1.11 Product-market coverage 47

1.12 Strategic positions in the market 48

1.13 Market structure and share positions 49

1.14 Market share (per cent) 56

1.15 Recent financial performance 58

1.16 Approaches to exporting 63

2.1 Advantages and limitations of branding policies $\quad 76$

2.2 Brand strategy guidelines for a market leader in different market structures and market conditions 81

2.3 Brand strategy guidelines for non-dominant firms in different competitive conditions and market conditions $\quad 82$

2.4 Product-market strategies 92

2.5 Two strategy packages 95

2.6 Andrex as market leader 106

2.7 Glaxo financial performance 109

2.8 Glaxo co-marketing agreements for Zantac 110

3.1 The marketing mix for services 118

3.2 Selected European representation of major EC grocery retailers 121

3.3 Turnover of the major European grocery retailers, 1987/88 123

3.4 Comparison of the turnover of European grocery buying groups vs. the European Retail Association 126

3.5 UK food sales by sector, 1980-8 (unit per cent value analysis) 128

3.6 Net profit as a per cent of sales of selected European grocery retailers 128

3.7 Ratners' Group plc Financial Summary, 1988-92 143

3.8 Generic strategies and market perceptions 147

3.9 Challenger strategies in rapid growth markets 149 
3.10 Challenger strategies in mature markets 150

3.11 Amstrad plc financial performance, 1983-92 157

3.12 Amstrad plc results, 1991 and $1992 \quad 158$

3.13 Comparison of Tesco's marketing mix before and after $1977 \quad 168$

3.14 Tesco financial record, 1988-92 169

3.15 Tesco plc financial performance 170

3.16 Bernard Matthews plc financial record, 1988-92 178

4.1 Detailed profit and loss figures, 1973-83 201

4.2 Profit and loss account, 1981-3 202

4.3 Argos financial performance, 1988-92 211

5.1 Infiltration strategies and competitor types 279

5.2 Rapid penetration strategies and competitor types 280

5.3 Trivial Pursuit: European unit sales 290

5.4 The March of the Lilac Cow (Lila Pause): market shares of Milka and Sprengel chocolate bars (per cent) 299

5.5 Market shares of competitors in West Germany, 1989300

5.6 The UK retail clothing market, 1976-82 302

5.7 Hepworth Group financial performance, 1976-81 307

5.8 Hepworth Group financial performance, 1982-8 307

5.9 Next plc financial performance, 1988-92 310

5.10 Thornton's plc financial record, 1988-92 320 


\section{List of Figures}

1.1 Strategies to achieve future position 1

1.2 Strategy formulation process 4

1.3 Life-cycle of a typical product 7

1.4 Diffusion pattern and adopter categories 9

1.5 Basic product life-cycle stages 10

1.6 Alternative life-cycle shape and stages 11

1.7 Profit-volume relationship over the life-cycle 11

1.8 Generalised diffusion pattern for a fad, a fashion and a new product 11

1.9 The commodity slide 13

1.10 Experience cost relationships 14

1.11 A typical stable pattern 15

1.12 A characteristic unstable pattern after it has become stable 15

1.13 Competitor and industry price experience 16

1.14 Unstable price gap 16

1.15 Portfolio positions and cash flows 20

1.16 Strategy direction 24

1.17 Product market directions 25

1.18 Gap analysis 25

1.19 Strategy alternatives for closing the gap 28

1.20 The five competitive forces and elements of industry structure

1.21 Strategic alternatives 34

1.22 Strategic directions 35

1.23 Portfolio, life-cycle and market share 43

1.24 Improving competitive position 44

1.25 The path to competitive position taken by Japanese car manufacturers 44

1.26 The path to competitive position in McDonald's 46

1.27 Improving competitive position 52

1.28 Schematic diagram of Blue Circle Industrial Group corporate structure 54

1.29 UK radiator market, 1960 to date 55

1.30 Directional policy matrix - Round Top 61

1.31 Directional policy matrix - Supaline 61

1.32 Product innovation continuum 62

1.33 Porter's strategy matrix 65

1.34 Organisational positioning of sales and radiators divisions 66

1.35 Distribution chain 67

1.36 SWOT analysis for Myson radiators 
2.1 Product/division profit improvement options 94

2.2 A 'differentiated, plus cost advantage' strategy is best, but requires superior quality of management 96

2.3 Market size for Backhoe Loaders, 1972-81 97

2.4 Housing and construction 98

2.5 Product life-cycle 99

2.6 Sitemaster market growth, 1981-7 100

2.7 Sitemaster sales, 1981-7 100

2.8 Market share of toilet tissue manufacturers 103

2.9 Porter's generic strategies 104

2.10 Price and competition 105

2.11 Glaxo financial performance to $1992 \quad 108$

2.12 Ansoff matrix of Zantac Business Development 110

2.13 Zantac market penetration by country, $1986 \quad 111$

3.1 GDP and population of the world's leading commercial powers, $1988 \quad 120$

3.2 Structure of UK grocery retailing, $1989 \quad 123$

3.3 Porter's structural framework 124

3.4 The cycle of retail concentration 126

3.5 A jewellers covering all areas of the market from high price high quality to low price low quality 141

3.6 Individual coverage of the entire jewellery market 141

3.7 Price Pincer patterns 149

3.8 The Japanese strategic marketing planning model $\quad 150$

3.9 Japanese automobiles 151

3.10 Japanese motorcycles 152

3.11 Amstrad's turnover in major European countries, 1984 and $1988 \quad 154$

3.12 The life-cycle of Amstrad products, 1984-8 155

3.13 Amstrad's product portfolios, 1985 and $1989 \quad 156$

3.14 Market map, newspapers 161

3.151986 market map, newspapers 162

3.16 Competitive positioning and management focus 165

3.17 Bernard Matthews Ltd, planning gap in mid-1970s 173

3.18 Bernard Matthews, SWOT analysis in mid-1970s 174

3.19 Bernard Matthews, Porter matrix 175

3.20 Bernard Matthews, Boston box 176

3.21 Bernard Matthews, sales turnover 1978-86 177

4.1 Boston matrix: Spanish spirit market from $1982 \quad 187$

4.2 Spanish spirit market development, 1982- 187

4.3 Spanish whisky market share, 1982-91 188

4.4 Relative differentiation for competitive advantage 190

4.5 Examples of advertising used in Hornes 1975 promotional campaign 199

4.6 Further examples of advertising used in Hornes 1975 promotional campaign 200 
4.7 Store layout 201

4.8 Institutional life-cycle effects in food retailing 205

4.9 Acrylic fibre supply to the UK, 1976-87 219

4.10 SWOT analysis of Courtelle in $1980 \quad 219$

4.11 Selincourt plc: pre-tax profits, 1958-83 248

4.12 Selincourt plc: group turnover, 1967-83 248

4.13 Selincourt plc: debt/equity ratios, 1968-83 249

5.1 Share trends 261

5.2 Marketing effort trends 261

5.3 Alternative directions for competitive growth for the small specialised firm 263

5.4 Competitive strategy directions for a defined market 265

5.5 Brent Chemicals International plc sales, 1990 (and 1992 after restructuring) 267

5.6 Brent Chemicals International plc geographical analysis of sales, 1990 (and 1992) 267

5.7 Brent Chemicals International plc sales 1989 pre-restructuring 269

5.8 Brent Chemicals International plc current structure 271

5.9 Distribution channel relationships 278

5.10 Firkin Pubs SWOT analysis 284

5.11 San Serif's product/market matrix in $1987 \quad 287$

5.12 Trivial Pursuit UK and European unit sales, 1983-8 288

5.13 Trivial Pursuit's new products and new markets 289

5.14 Derwent Valley product portfolio 292

5.15 Derwent Valley diversification 293

5.16 Retail clothing - late 1970s/early 1980s 303

5.17 Hepworth's profits, 1978-82 304

5.18 Next turnover, 1982-8 308

5.19 Next profit after tax, 1982-8 309

5.20 Next Ansoff matrix in $1988 \quad 310$

5.21 Market gap analysis 313

5.22 Thorntons Boston matrix 317

5.23 Thorntons directional policy matrix 318

5.24 Thorntons Porter matrix 318

6.1 Generic strategic positions 323

6.2 Strategic directions 324

6.3-6.14 Matrices showing strategy positions and strategic directions for each of the case studies features 325

6.15 Evaluating strategic options 335 


\section{Acknowledgements}

The authors and publishers wish to thank the following for permission to use copyright material:

American Marketing Association for material from B. H. Booms and M. J. Bitner, 'Marketing Strategies and Organisation Structures for Service Firms' in Marketing of Services, eds J. Donnelly and W. R. George, 1981; Amstrad plc for material from their 1992 Annual Report and Accounts; The Boston Consulting Group, Inc. for material from 'Perspectives on Experience', 1970; Steve Burt for material from J. Dawson and S. Burt, 'The Evolution of European Retailing', Institute for Retail Studies/ICL, 1988; Butterworth-Heinemann Ltd for material from M. McDonald, How to Prepare Marketing Plans, 1989; The Free Press, a division of Macmillan Inc., for material from Michael E. Porter, Competitive Strategy: Techniques for Analyzing Industries and Competitors - copyright (C) 1980 by The Free Press; Glaxo Holdings plc for material from their 1992 Report and Accounts; Bernard Matthews plc for material from their 1992 Report and Accounts; MCB University Press for material from A. Meenaghan and P. W. Turnbull, 'Strategy and Analysis in Product Development', European Journal of Marketing, 15, 5, 1981, and from D. T. Browlie and C. K, Bart, Products and Strategies, 1985; Next plc for material from their 1992 Report and Accounts; Prentice Hall International (UK) Ltd for material from D. Knee and D. Walters, Strategy in Retailing, 1985; Signet Group plc for material from Ratners 1992 Annual Report and Accounts, Interim Report; Tesco Stores Ltd for material from their 1992 Annual Report and Accounts and Interim Report; Thorntons plc for material from their 1992 Annual Report and Accounts; West Publishing Corporation for material from G. S. Day, Strategic Market Planning, 1984, figs 7.3, 5.6, 3.1 - copyright (C) 1984 by West Publishing Company, and from G. S. Day, Analysis for Strategic Market Decisions, 1986, 7.4, A.7, A.10, 6.8, 7.3, 3.1 copyright (C) 1986 by West Publishing Company; John Wiley and Sons Inc. for material from D. A. Aaker, Strategic Market Management, 1992; Yoram Wind for material from Product Policy: Concepts, Methods and Strategy, Addison-Wesley, Inc., 1982.

Every effort has been made to trace all the copyright holders but if any have been inadvertently overlooked the publishers will be pleased to make the necessary arrangement at the first opportunity.

Above all, this book would not have been possible without the extremely efficient and timely help of Clare Argent, a Cranfield MBA. Her attention to detail kept us both on the rails throughout the production of the book. Furthermore, her insight, vision and continuous advice helped turn what may have been an adequate book into what we believe is now a very good one. 